Collection: EFI 2008 Annual Conference Week - Orvieto (Italy) Adaptation of Forest Landscape to Environmental Changes Guest Editor: Giuseppe Scarascia Mugnozza (CRA - Rome, Italy)

\section{Networking sampling of Araucaria araucana (Mol.) K. Koch in Chile and the bordering zone of Argentina: implications for the genetic resources and the sustainable management}

\author{
Drake $F^{(1)}$, Martín MA ${ }^{(2)}$, Herrera MA ${ }^{(3)}$, Molina JR ${ }^{(3)}$, Drake-Martin F ${ }^{(4)}$, \\ Martín LM ${ }^{(2)}$
}

\begin{abstract}
Araucaria araucana, a southern South American tree species, is considered a representative symbol of Chilean forest biodiversity due to its endemicity and longevity. An expedition to Chile and its border zone with Argentina was carried out with the aim of determining the current state of this species and to establish a tree network to study its genetic variability. Eight locations were selected across the range of distribution of the species and several experimental plots were established based on the heterogeneity within each location. Field trips revealed a high fragmentation in Araucaria forests showing low or non-existent regeneration in most of its distribution area. Experimental plots allowed the identification of severely altered areas. Moreover, 371 trees were catalogued, 193 males and 178 females. The tree network established will be very useful in future evaluations of both the ecological status of the species and its genetic resources, allowing the development of conservation strategies.
\end{abstract}

Keywords: Araucaria araucana, biodiversity, ecological attributes, genetic resources

\section{Introduction}

The Chilean native forest and that in the Argentinean border zone include more than one hundred species and constitute one of the forest ecosystems richest in biodiversity in the world (Movimiento Mundial por los Bosques 1998). Within forest formations Araucaria araucana (Mol.) K. Koch stands out as the dominant species given its particular characteristics. Indeed, it is considered a representative symbol of the Chilean forest biodiversity due to its endemicity and its longevity (Hoffmann et al. 2001).

Araucaria distribution is fragmented and restricted to some specific areas in Chile and Argentina. In Chile, it covers over 261000 ha representing about $65 \%$ of the total area in which it is found. The principal location is situated in the Andean Cordillera at latitudes between $37^{\circ} 30^{\prime}$ ' and $39^{\circ} 30^{\prime} \mathrm{S}$, in Bio-Bio and Araucania Regions and there are some isolated stands in the north Andean limit in the Lakes Region. The second area is found in the coastal cordillera (Nahuelbuta Cordillera) between $37^{\circ} 20^{\prime}$ and $38^{\circ} 40^{\prime} \mathrm{S}$ (Veblen 1982). In Argentina the species covers a restricted area at latitudes between $37^{\circ} 45^{\prime}$ and $40^{\circ} 20^{\prime} \mathrm{S}$.

A. araucana occurs in either pure or mixed species stands along with Nothofagus spp. at an elevation of between 1000 and $1600 \mathrm{~m}$. It is associated with coigüe (Nothofagus dombeyi Mirb. Oerst.) and seldom with oak (Nothofagus obliqua Mirb. Oerst. var.) in the lower altitudes, with coigüe and lenga (Nothofagus pumilio Poepp. et Endel. Krasser) in medium altitudes and only with lenga at upper forest limits (Gajardo 1980, Donoso 1981, Veblen et al. 1995).

$A$. araucana is dioecious, but it can occasionally be monoecious with pollen predominantly dispersed by wind and gravity seed (Muñoz 1984; Heusser et al. 1988). It also regenerates vegetatively by sprouting and root suckering (Schilling \& Donoso 1976, Veblen 1982, Donoso 1993).

The araucaria's current distribution is a remnant of a more extensive former distribution that was severely diminished by the intense exploitation of the species in the past. Other factors which have a great impact are domestic herbivores and seed harvest (Tortorelli 1942, Veblen 1982, Aagesen 2004, Bekessy et al. 2004) and forces of
(1) Departamento de Manejo de Bosques y Medioambiente, Facultad de Ciencias Forestales, Universidad de Concepción, Casilla 160-C, Concepción (Chile); (2) Departamento de Genética, Escuela Técnica Superior de Ingenieros Agrónomos y de Montes, Edificio Gregor Mendel, Campus de Rabanales, Universidad de Córdoba, ES14071 Córdoba (Spain); (3) Departamento de Ingeniería Forestal, Escuela Técnica Superior de Ingenieros Agrónomos y de Montes, Edificio Leonardo Da Vinci, Universidad de Córdoba, ES-14071 Córdoba (Spain); (4) Private Company, León Gallo 0548, Temuco (Chile)

@, Angela Martín (ge2macum@uco.es)

Received: Apr 08, 2009 - Accepted: Nov 09, 2009

Citation: Drake F, Martín MA, Herrera MA, Molina JR, Drake-Martin F, Martín LM, 2009. Networking sampling of Araucaria araucana (Mol.) K. Koch in Chile and the bordering zone of Argentina: implications for the genetic resources and the sustainable management. iForest 2: 207-212 [online: 2009-12-22] URL:

http://www.sisef.it/iforest/show.php? id $=524$

nature as wind, volcanism and fire (Veblen 1982, Burns 1993). As a result, conservation of the species is a subject of great concern given its restricted distribution, slow growth and poor regeneration capacity which make it particularly susceptible to external pressures (Montaldo 1974, Mutarelli \& Orfila 1992, Paulsch 1994). It is included in Appendix I of the Convention on International Trade of Endangered Species of Wild Flora and Fauna (CITES) and is listed as a "vulnerable" species on the Red Data list published by the International Union for Conservation of Nature (IUCN 1996). Furthermore, in Chile in the Supreme Decree 43, araucaria is classed as a national monument and is officially protected.

Although this species is not under imminent risk of extinction, its structure and natural forest dynamic show deep perturbations (Burns 1991, Drake et al. 2005, Donoso 2006). In order to assess whether ongoing patterns of habitat fragmentation could threaten its genetic resources and its evolutionary potential, it is necessary to explore the genetic diversity and ecological attributes across the range of the species. Even more, the correlation of genetic data with ecological and geographic variables may show more complete information about the state of the species. In fact, Turner (2001) mentioned that by combining all these aspects areas of potential conservation sites may be identified.

Studies based on the spatial distribution of 
the araucaria's genetic variation have been conducted using different markers as gas liquid chromatography (Rafii \& Dodd 1998), isozymes (Gallo 2003) and RAPDs (Bekessy et al. 2002, Bekessy et al. 2003). These studies indicated that genetic diversity is high and unaffected by the ecological heterogeneity of the species. Nevertheless, in recent years other DNA markers have proved to be more suitable for studying population genetic diversity as microsatellite or simple sequence repeats (SSRs). In fact, the identification of markers linked to genes involved in the adaptive response to environmental changes could contribute to define criteria to plan conservation strategies as is the case of EST-based SSRs. Moreover, there is no record relating to the temporal distribution of araucaria genetic diversity, that is, if the decrease in the surface area occupied by the species has caused changes in the genetic composition of young trees in relation to the older ones. In fact, in other woody plants as Olea europaea L., it has been demonstrated that older individuals include allelic variants that are not present in new stands (MuñozDiez 2008). It is therefore of particular importance the establishment of a tree network which will allow the monitoring of the state of the genetic resources and the role of each stand in the conservation of the species.

In this study an expedition to the areas of $A$. araucana distribution was conducted to determine the current state of the species and to establish a tree network for future evaluation of its genetic variability and its spatial and temporal distribution. Specifically, further evaluations of ecological and germplasm data may allow the detection of possible threats to the genetic resources of the species and the development of conservation strategies to restore these degraded areas.

\section{Material and Methods}

\section{Study area}

Aerial photographs and satellite imagery were used to select the study area. These fulfilled two objectives, the stratification and the initial plot measurement, both carried out in Concepción University (Chile). Geographic Information System (GIS) software was also used to provide information on the

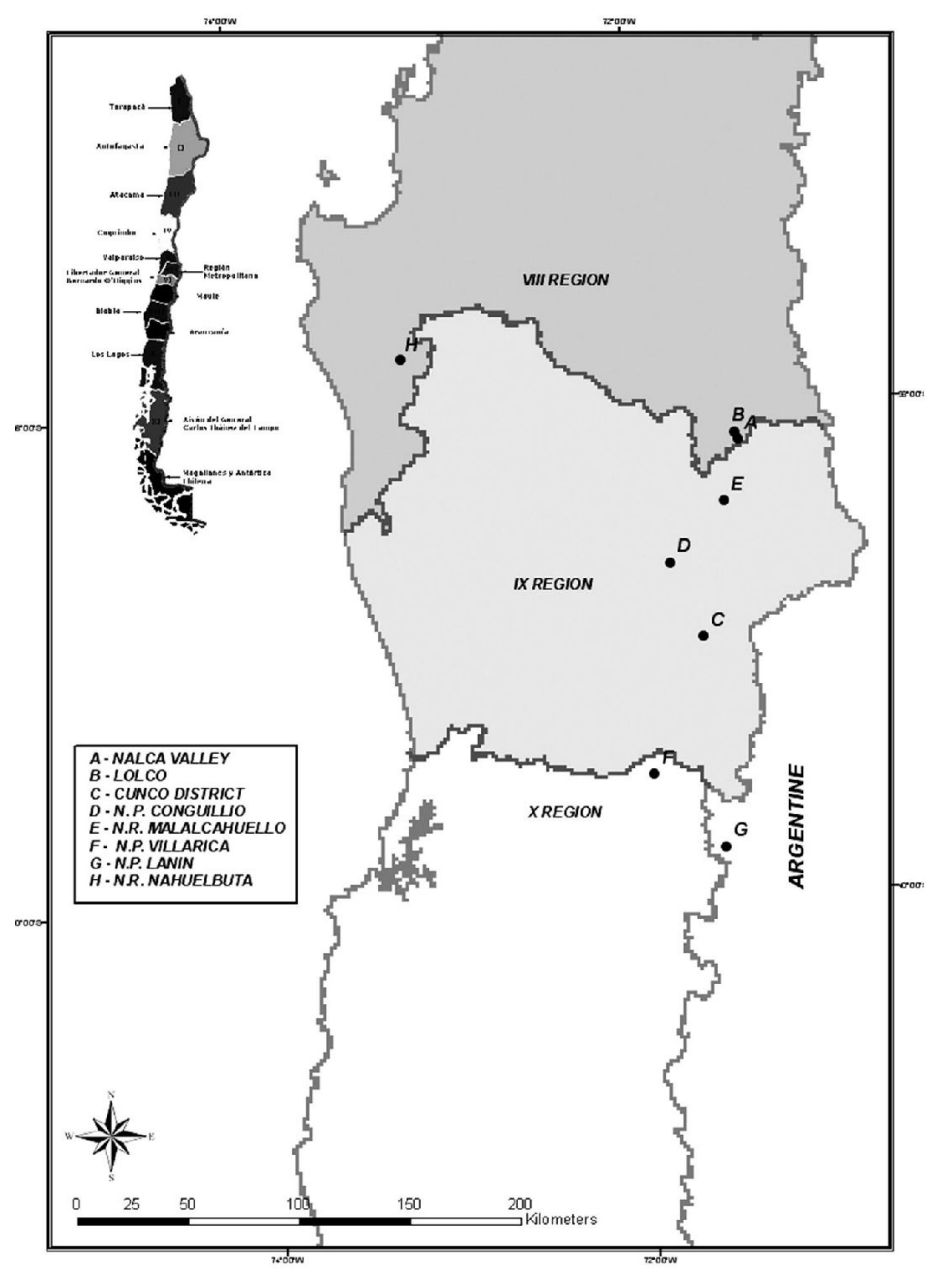

Fig. 1 - Map showing the eight locations sampled in the collecting mission in Chile and Argentina.

status and condition of the araucaria forests. Coverage included all forested lands in Chile: private and public.

Permanent sample plots have been recognised as an interesting approach in determining changes in forests. This type of sampling has two objectives: to provide a description of the stand and to determine areas to be repeatedly measured over time. Accordingly, this permanent method was used for establishing the tree network to detect changes in araucaria regeneration.

With this basic information, field trips were carried out from March to April 2007 across the species range. Field trips were based on one field sample site of 261000 ha. The tree network was designed by an expert panel (DELPHI method) covering as many different habitats as possible.

The locations chosen for this study included areas from both the Chilean and Argentinean sides of the Andean Cordillera and the coastal range of Chile (Fig. 1). According to climatic, ecological and geographical attributes, eight locations were identified and catalogued, seven in the Andean Cordillera

Tab. 1 - Data of latitude, longitude and altitude measured in each location in Chile and Argentina.

\begin{tabular}{|c|c|c|c|c|c|c|}
\hline Area & Region & Location & Latitude (S) & Longitude (W) & Altitude (m) & Country \\
\hline \multirow[t]{7}{*}{ Andean Cordillera } & Bio-Bio (VIII) & Nalca Valley & $38^{\circ} 17^{\prime}$ & $71^{\circ} 27^{\prime}$ & $1200-1500$ & Chile \\
\hline & & Lolco & $38^{\circ} 16^{\prime}$ & $71^{\circ} 28^{\prime}$ & $990-1000$ & Chile \\
\hline & Araucania (IX) & Cunco District & $38^{\circ} 57^{\prime}$ & $71^{\circ} 40^{\prime}$ & $1200-1450$ & Chile \\
\hline & & Conguillio N.P. & $38^{\circ} 39^{\prime}$ & $71^{\circ} 50^{\prime}$ & $1100-1170$ & Chile \\
\hline & & Malalcahuello N.R. & $38^{\circ} 25^{\prime}$ & $71^{\circ} 32^{\prime}$ & $1350-1430$ & Chile \\
\hline & Lakes (X) & Villarrica N.P. & $39^{\circ} 32^{\prime}$ & $71^{\circ} 57^{\prime}$ & $950-1000$ & Chile \\
\hline & & Lanin N.P. & $39^{\circ} 47^{\prime}$ & $71^{\circ} 40^{\prime}$ & $1000-1100$ & Argentina \\
\hline Coastal Cordillera & (IX) & Nahuelbuta N.R. & $37^{\circ} 48^{\prime}$ & $71^{\circ} 57^{\prime}$ & $1200-1400$ & Chile \\
\hline
\end{tabular}


Tab. 2 - Ecological attributes measured in the eight locations in Chile and Argentina.

\begin{tabular}{|c|c|c|c|c|c|c|c|c|c|}
\hline \multirow[b]{2}{*}{ Plot } & \multirow[b]{2}{*}{ Name } & \multirow{2}{*}{$\begin{array}{c}\text { Stand } \\
\text { composition }\end{array}$} & \multirow{2}{*}{$\begin{array}{l}\text { Understory } \\
\text { composition }\end{array}$} & \multirow{2}{*}{$\begin{array}{l}\text { Slope } \\
(\%)\end{array}$} & \multirow[b]{2}{*}{ Aspect } & \multicolumn{2}{|c|}{ Regeneration } & \multirow{2}{*}{$\begin{array}{c}\text { Stand } \\
\text { development }\end{array}$} & \multirow[b]{2}{*}{ Observations } \\
\hline & & & & & & $\begin{array}{l}\text { full shade } \\
\text { zone }\end{array}$ & $\begin{array}{l}\text { open } \\
\text { zone }\end{array}$ & & \\
\hline 1 & Nalca Valley & $\begin{array}{l}\text { Nothofagus } \\
\text { antartica } \\
(20 \%)\end{array}$ & Chusquea quila & $5-15$ & $\begin{array}{l}\text { South- } \\
\text { Eastern }\end{array}$ & Low & High & Even aged & Volcanic soil \\
\hline 2 & Lolco & - & $\begin{array}{l}\text { Nothofagus antartica; } \\
\text { Chusquea quila }\end{array}$ & $0-5$ & $\begin{array}{l}\text { North- } \\
\text { Western }\end{array}$ & None & None & Old grown stage & Dense shrub load \\
\hline 3 & $\begin{array}{l}\text { Cunco } \\
\text { District }\end{array}$ & $\begin{array}{l}\text { Nothofagus } \\
\text { dombeyi } \\
(50 \%)\end{array}$ & $\begin{array}{l}\text { Drymis winteri; } \\
\text { Chusquea culeu; } \\
\text { Nothofagus dombeyi }\end{array}$ & $15-30$ & South & Low & None & Even aged & - \\
\hline 4 & $\begin{array}{l}\text { Cunco } \\
\text { District }\end{array}$ & $\begin{array}{l}\text { Nothofagus } \\
\text { dombeyi } \\
(90 \%)\end{array}$ & $\begin{array}{l}\text { Drymis winteri; } \\
\text { Chusquea culeu; } \\
\text { Nothofagus dombeyi }\end{array}$ & $5-15$ & Flat & Low & None & Even aged & - \\
\hline 5 & $\begin{array}{l}\text { Cunco } \\
\text { District }\end{array}$ & $\begin{array}{l}\text { Nothofagus } \\
\text { pumilio }(70 \%)\end{array}$ & $\begin{array}{l}\text { Nothofagus pumilio fire- } \\
\text { wood }\end{array}$ & $5-15$ & North & High & High & Uneven aged & Cattle \\
\hline 6 & $\begin{array}{l}\text { Conguillio } \\
\text { N. P. }\end{array}$ & $\begin{array}{l}\text { Nothofagus } \\
\text { dombeyi } \\
(40 \%)\end{array}$ & Chusquea quila & $0-5$ & Flat & Medium & None & Uneven aged & Lava cone \\
\hline 7 & $\begin{array}{l}\text { Conguillio } \\
\text { N.P. }\end{array}$ & $\begin{array}{l}\text { Nothofagus } \\
\text { dombeyi (5\%) }\end{array}$ & $\begin{array}{l}\text { Chusquea quila; Persea } \\
\text { lingue regeneration }\end{array}$ & $0-5$ & Flat & Low & None & Uneven aged & Lava descendent way \\
\hline 8 & $\begin{array}{l}\text { Malalcahuello } \\
\text { N. R. }\end{array}$ & - & $\begin{array}{l}\text { Nothofagus antartica; } \\
\text { Podocarpus saligna }\end{array}$ & $5-15$ & $\begin{array}{l}\text { North- } \\
\text { Eastern }\end{array}$ & High & Medium & Even aged & $\begin{array}{l}\text { Presence of recent vol- } \\
\text { canic ash }\end{array}$ \\
\hline 9 & $\begin{array}{l}\text { Malalcahuello } \\
\text { N. R. }\end{array}$ & - & Grassland & $0-5$ & Flat & High & High & Uneven-age & Stand altitude limit \\
\hline 10 & $\begin{array}{l}\text { Malalcahuello } \\
\text { N. R. }\end{array}$ & 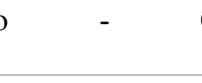 & Grassland & $5-15$ & $\begin{array}{l}\text { South- } \\
\text { Eastern }\end{array}$ & Medium & None & Uneven-age & Stand altitude limit \\
\hline 11 & $\begin{array}{l}\text { Villarica } \\
\text { N.P. }\end{array}$ & $\begin{array}{l}\text { Nothofagus } \\
\text { dombeyi } \\
(10 \%)\end{array}$ & $\begin{array}{l}\text { Nothofagus antartica; } \\
\text { Persea lingue; } \\
\text { Chusquea quila }\end{array}$ & $0-5$ & $\begin{array}{l}\text { North- } \\
\text { Eastern }\end{array}$ & None & None & Even aged & $\begin{array}{l}\text { Sparce regeneration. } \\
\text { Thalweg }\end{array}$ \\
\hline 12 & Lanin N. P. & $\begin{array}{l}\text { Nothofagus } \\
\text { dombeyi } \\
(10 \%)\end{array}$ & $\begin{array}{l}\text { Nothofagus antartica; } \\
\text { Persea lingue; } \\
\text { Chusquea quila }\end{array}$ & $0-5$ & South & Low & None & Even aged & - \\
\hline 13 & Lanin N. P. & - & Grassland & $0-5$ & Flat & None & None & Old grown & Steppe \\
\hline 14 & $\begin{array}{l}\text { Nahuelbuta } \\
\text { N. R. }\end{array}$ & $\begin{array}{l}\text { Nothofagus } \\
\text { dombeyi } \\
(50 \%)\end{array}$ & $\begin{array}{l}\text { Drymis winteri; Persea } \\
\text { lingue; Chusquea quila }\end{array}$ & $5-15$ & South & Medium & Medium & Even aged & Rocky surface \\
\hline 15 & $\begin{array}{l}\text { Nahuelbuta } \\
\text { N. R. }\end{array}$ & $\begin{array}{l}\text { Nothofagus } \\
\text { dombeyi (5\%) }\end{array}$ & $\begin{array}{l}\text { Nothofagus antartica; } \\
\text { Chusquea quila }\end{array}$ & $5-15$ & North & Low & Medium & Even aged & $\begin{array}{l}\text { Recreational area. Old } \\
\text { surface fire }\end{array}$ \\
\hline
\end{tabular}

and one in the Nahuelbuta Cordillera (Tab. 1). Depending on the ecosystems heterogeneity, between one and three circular plots $\left(1000 \mathrm{~m}^{2}\right)$ were installed within each location. Specifically, three plots were identified in Cunco District and Malalcahuello N.R, two plots in Conguillio N.P., Lanin N.P. and Nahuelbuta N.R. and one plot in Lolco, Nalca Valley and Villarrica (Tab. 2).

\section{Assessments}

The position of all trees in each plot was mapped and data of their altitude, latitude and longitude were measured using the Geographical Positioning Satellite system (GPS). Selected trees were located in a latitude range from $37^{\circ} 48^{\prime} \mathrm{S}$ to $39^{\circ} 47^{\prime} \mathrm{S}$ and an altitude range from 950 to $1500 \mathrm{~m}$.

In each site, tree diameter, understory species, natural regeneration and topographic at- tributes were measured within each plot (Tab. 2). Stands were evaluated according to their composition and development. For the stand composition, the percentage of associated species was calculated according to the total density of Araucaria and Nothofagus trees (Tab. 2). The araucaria structure was classified into three categories: evenaged, uneven-aged and old growth. The understory was described in terms of composition and plant cover and topographical conditions expressed through measurements of slope and aspect. Gap-phase regeneration is considered to be the common way in which forests are renewed due to the suitable conditions for the establishment of seedlings. Araucaria seedling growth is slow until the canopy opening is created. For this, araucaria regeneration was classified into two types depending on the possibility of seedling establishment: full shade zone and open zone. Open zone regeneration is the cornerstone of the species natural dynamics because of its slow growth and the competition from undergrowth species. Natural regeneration in each plot was established through visual estimation into four qualitative levels according to the seedling number: none ( $>50$ seedlings per ha), low (50-300 seedlings per ha), medium (300-600 seedlings per ha) and high $(<600$ seedlings per ha).

To estimate the genetic diversity, the criterion was to catalogue 30 female and 30 male trees in each location, given that araucaria is a dioecious species. In the case of female individuals, seeds from each tree were collected for future genetic analyses using three age classes: thicket $(<50$ years $)$, polewood (100-200 years) and all growth ( $>$ 
Tab. 3 - Ecological attributes measured in the eight locations - DBH: diameter at breast height.

\begin{tabular}{cccccl}
\hline $\begin{array}{c}\text { Index } \\
\text { site }\end{array}$ & $\begin{array}{c}\text { DBH } \\
(\mathbf{c m})\end{array}$ & $\begin{array}{c}\text { Height } \\
(\mathbf{m})\end{array}$ & $\begin{array}{c}\text { Temperature } \\
\text { range }\left(\mathbf{C}^{\mathbf{0}}\right)\end{array}$ & $\begin{array}{c}\text { Precipitation } \\
(\mathbf{m m})\end{array}$ & \multicolumn{1}{c}{ Location } \\
\hline 1 & 54.04 & 37 & $4.6 / 13.9$ & $2900-3300$ & Villarrica N.P, Lanin N.P. \\
2 & 40.39 & 30 & $-0.9 / 13.9$ & $3200-3500$ & Cunco District \\
3 & 57.86 & 25 & $5.4 / 26$ & $1300-1600$ & Nahuelbuta N.R \\
4 & 56.77 & 27 & -3 to $2 / 12$ & $1800-2050$ & $\begin{array}{l}\text { Nalca Valley, Lolco, } \\
\text { Conguillio N.P. }\end{array}$ \\
& & & & & \\
5 & 44.79 & 15 & $-3 / 12$ & $1850-2100$ & Malalcahuello N.R \\
\hline
\end{tabular}

400 years). The assignation of each tree to its age class was conducted according to the index site and the diameter class equation proposed by Drake et al. (2003) and modified specifically for araucaria by Peraza (2008):

$$
\text { Ageclass }=139.19 e^{0.0203 \cdot D B H}
$$

being DBH the diameter measured at breast height. In total, five index sites were calculated according to climatic and forestry attributes (Tab. 3).

\section{Results and Discussion}

\section{Description of Araucaria stands}

Concerning the different locations studied, the stand composition associated with Araucaria-Nothofagus was verified in six of the eight locations studied (Tab. 2), while pure stands were found in Malacahuello N.R., Lolco and one of the two plots in Lanin N.P. In this latter site, the stand was composed of wooded steppe with a low canopy and conical shaped trees typical of growth without competition (Fig. 2F).

Lolco and Lanin N.R. were the most fragmented areas (Fig. 2D). In Lolco, the low density of the species made plot establishment difficult $(<50$ trees/ha). Likewise, it was stated that this area was severely altered since no signs of regeneration were detected and the remaining individuals showed old grown state. According to Drake (2004), this might indicate that araucaria stands are in decline phase and will be lost in a short period of time. In Villarrica N.P. araucaria stands showed a good height growth, but without regeneration and with a low ratio fe-

male/male trees (Tab. 2 and 4). Nalca Valley and one of the plots in Conguillio N.P. showed medium levels of regeneration. Nevertheless, in Nalca Valley regeneration was found to be better in open zones while in Conguillio N.P. regeneration was found in full shade zones (Fig. 2A, 2B and 2C).

In Nahuelbuta Cordillera, araucaria showed medium levels of natural regeneration forming even aged stands associated with $N$. dombeyi (Tab. 2, Fig. 2E). Furthermore, due to the high forest density in these stands a higher proportion of trees were found with umbrella form. In Malalcahuello N.R. araucaria stands grew in different physiographical conditions (slope and aspect). In Cunco District, the stand (N. Dombeyi and N. Pumilo) and the canopy composition (percentage of associated species) displayed irregular natural regeneration (Tab. 2).

\section{Establishment of a tree network for the} genetic diversity analysis

Altogether, 371 trees were catalogued, 193 males and 178 females. Nevertheless, the different characteristics of the evaluated stands made our initial objective feasible in only two locations, Cunco District and Malalcahuello N.R. The target number of female trees was also achieved in two other sampling sites, Nalca Valley and Lanin N.R. and the target male in one more, Nahuelbuta N.R. (Tab. 4). The expected number of sampled trees was not attained in all locations due to the different states of the evaluated stands. The situation found in Villarrica N.R. and Lolco was more complicated than the aforementioned since the number of fe-
Tab. 4 - Number of female and male trees sampled in the collecting mission.

\begin{tabular}{lccc}
\hline \multicolumn{1}{c}{ Location } & $\mathbf{N}^{\mathbf{0}}$ Female trees & $\mathbf{N}^{\mathbf{0}}$ Male trees & $\mathbf{N}^{\mathbf{0}}$ Total trees \\
\hline Nalca Valley & 30 & 25 & 55 \\
Lolco & 3 & 5 & 8 \\
Cunco District & 30 & 37 & 67 \\
Conguillio N.P. & 25 & 22 & 47 \\
Malalcahuello N.R. & 30 & 39 & 69 \\
Villarrica N.P. & 8 & 20 & 28 \\
Lanin N.P. & 31 & 0 & 31 \\
Nahuelbuta N.R. & 21 & 45 & 66 \\
Total & 178 & 193 & 371 \\
\hline
\end{tabular}

male trees was very low ( 8 and 3 , respectively) and in the latter this was also the case with respect to the number of male trees (Tab. 4). In fact, in Lolco the ecological situation was highly altered and with alarming density levels (Tab. 2). These results reveal that the trees listed in this study are the only remaining of the species in these areas (Tab. 4). Given all this, the impossibility to attain the sampling target is clear proof of the threat to its genetic diversity.

Nevertheless, we consider that not only the number of catalogued trees but also their distribution (spatial, sexes and age classes) is an excellent basis for genetic analysis, providing for a first round examination of the species from a broad distribution range and allowing the identification of further areas of interest.

Our future goal, whenever funding will be available, would be to address the above studies using genetic markers as seed storage proteins and SSRs. Indeed, the former have been used as an estimator of the genetic diversity in forest species (Álvarez et al. 2003, Álvarez et al. 2004, Martín et al. 2005, Martín et al. 2008) and in the case of conifers this technique is particularly favourable, given the haploid nature of the reserve tissue.

In fact, as the collecting mission was carried out in the fruit ripening period, an additional activity of sampling seeds from all female trees was undertaken. We consider that the use of both kinds of the above markers will provide good information to set up lines of action aimed to ensure the preservation of the species genetic resources and its survival for future generations.

\section{Conclusions}

The expedition showed that the natural regeneration of A. araucana is low or nonexistent in most of its distribution range, and this is the most evident sign of araucaria forests degradation. Furthermore, the state of degradation is such that the aim of establishing a tree network to be used in genetic diversity studies was only partially achieved.

Taking into account both regeneration ability and the total number of catalogued trees in each site, the best conserved areas were Malalcahuello N.R., Cunco District and Nahuelbuta N.R. Conversely, a severely altered situation was detected in Villarrica N.R., Lanin N.R. and Lolco. In fact, preliminary results allowed areas of dramatic landscape alteration to be identified as Lolco, which according to the available information has experienced an extensive loss of populations throughout its distribution range. This should be a priority area for conservation because if the current will persist, the above araucaria population will be lost, as it happened with other habitats.

To sum up, the complex structure and dis- 


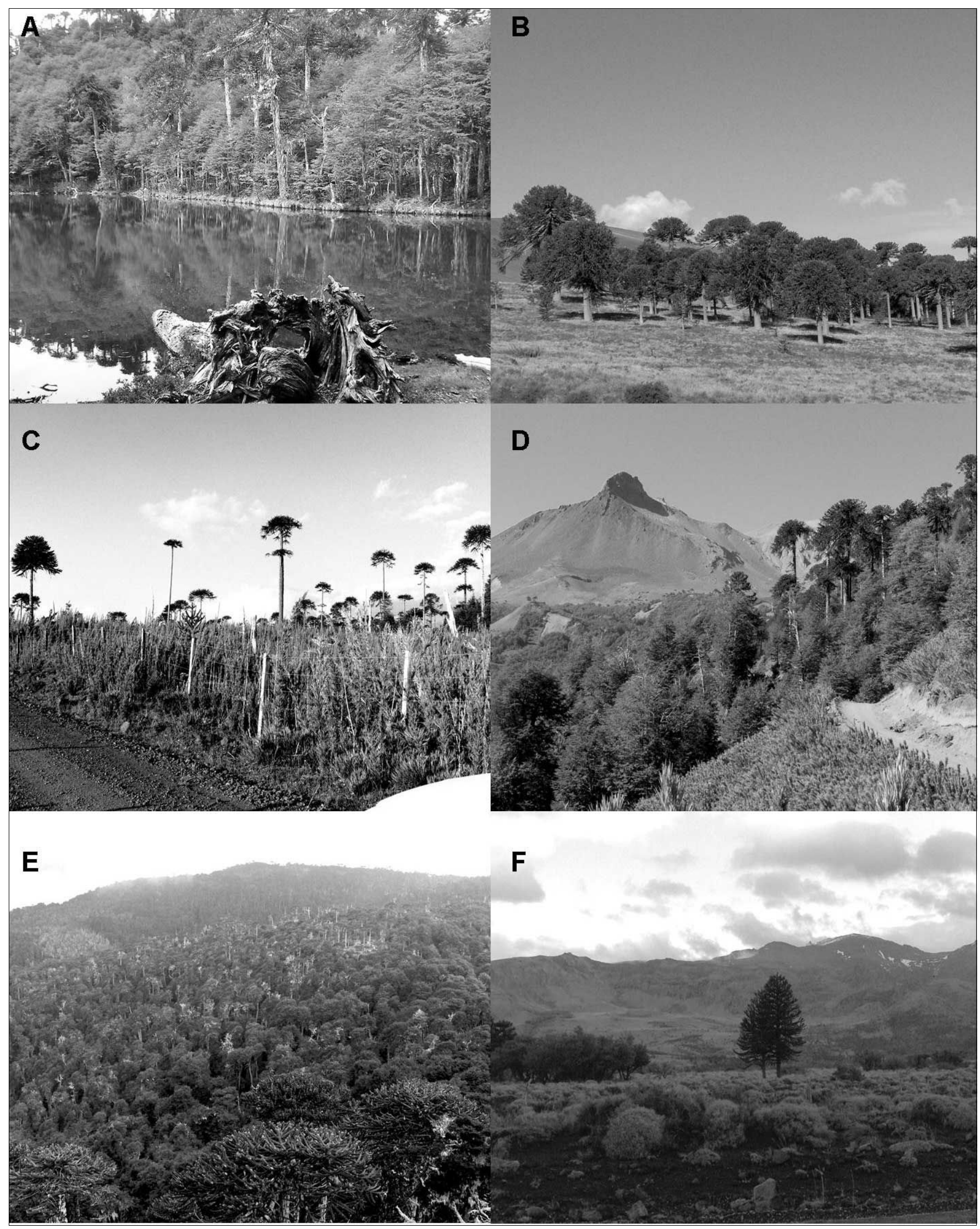

Fig. 2 - A representative sample of the A. araucana different habitats catalogued in Chile and Argentina. A) Cunco District (Chile); B) Malalcahuello N.R. (Chile); C) Conguillio N.P. (Chile); D) Lolco (Chile); E) Nahuelbuta N.R. (Chile) and F) Lanin N.P. (Argentina). 
tribution range of the species makes a strategic approach necessary to conserve the genetic resources of the species and guarantee its future. In fact, the genetic studies that can be carried out on the basis of this tree network will be of great utility for the development of this strategy.

\section{Acknowledgments}

This research was partially supported by grant No. 207.141.018-1.0 from the Research Service of Concepción University (Chile) and by grant B/6585/06 of the Spanish Agency of International Cooperation (AECI) from the Ministry for Foreign Affairs and Cooperation (Spain).

\section{References}

Aagesen DL (2004). Burning monkey-puzzle: native fire ecology and forest management in northern Patagonia. Agriculture and Human Values 21 (2-3): 233-242. - doi: 10.1023/B:AHUM $0000029402.85972 .6 \mathrm{c}$

Álvarez JB, Muñoz C, Martín MA, López S, Martín LM (2003). Cotyledon storage proteins as markers of the genetic diversity in Castanea sativa Miller. Theoretical and Applied Genetics 107: 730-735. - doi: 10.1007/s00122-003-1298-9 Álvarez JB, Toledo MJ, Abellanas B, Martín LM (2004). Use of megagametophyte storage proteins as markers of the genetic diversity in stone pine (Pinus pinea L.) in Andalusia, Spain. Genet. Res. and Crop Evol. 51: 621-627. - doi: 10.1023/B:GRES.0000024647.74194.4e

Bekessy SA, Allnut TR, Premoli AC, Lara A, Ennos RA, Burgman MA, Cortes M, Newton AC (2002). Genetic variation in the vulnerable and endemic Monkey Puzzle tree, detected using RAPDs. Heredity 88: 243-249. - doi: 10.1038/ sj.hdy.6800033

Bekessy SA, Ennos RA, Burgman MA, Newton AC, Ades PR (2003). Neutral DNA markers fail to detect genetic divergence in an ecologically important trait. Biol. Cons. 110: 267-275. - doi: 10.1016/S0006-3207(02)00225-2

Bekessy SA, Lara A, González M, Cortes M, Gallo L, Premoli AC, Adrian N, Izquierdo F (2004). Variación en Araucaria araucana (Molina) K.Koch. In: "Variación intraespecífica en especies arbóreas de los bosques templados de Chile y Argentina" (Donoso C, Premolia A Gallo L, Ipinza R eds). Editorial Universitaria, Santiago, Chile, pp. 215-232.

Burns BR (1991). The regeneration dynamics of Araucaria araucana. $\mathrm{PhD}$ thesis, University of Colorado, Bolder, USA, pp. 195

Burns BR (1993). Fire-induced dynamics of Araucaria araucana- Nothofagus antartica forest in the southern Andes. Journal of Biogeography
20: 669-685. - doi: 10.2307/2845522

Donoso C (1981). Tipos forestales de los bosques nativos de Chile. Documento de trabajo no. 38, Investigación y Desarrollo Forestal FAO/DP/ CHI/76/003, Santiago, Chile, pp. 70.

Donoso C (1993). Bosques templados de Chile y Argentina: variación, estructura y dinámica. Edición Universitaria, Santiago, Chile, pp. 308-351.

Donoso C (2006). Las especies arbóreas de los bosques templados de Chile y Argentina. Autoecología. Marisa Cúneo Ediciones, Valdivia, Chile, pp. 678.

Drake F, Emanueli P, Acuña E (2003). Compendio de funciones dendrométricas del bosque nativo. Proyecto de conservación y manejo sustentable del bosque nativo, Universidad de Concepción, CONAF y Sociedad Alemana de Cooperación Científica, Santiago, Chile.

Drake F (2004). Uso sostenible en bosques de Araucaria araucana (Mol.) K. Koch. Aplicación de modelos de gestión. PhD thesis, University of Cordoba, Spain

Drake F, Herrera MA, Acuña E (2005). Propuesta de manejo sustentable de Araucaria araucana (Mol.) C. Koch. Bosque 26 (1): 23-32. [online] URL: http://www.scielo.cl/scielo.php?pid=S0717 $-92002005000100003 \&$ script $=$ sci arttext\&tlng= en

Gajardo R (1980). Vegetación del bosque de Araucaria araucana (Mol.) C. Koch. en la Cordillera de los Andes (Lonquimay, provincia de Malleco). Boletín Técnico no. 57, Facultad de Ciencias Forestales, Universidad de Chile, Santiago, Chile, pp. 25

Gallo L (2003). Conservación, manejo y uso sustentable de los recursos genéticos de la Araucaria araucana en Argentina, Comunidades Aucapan y Chiuquilihuin, San Carlos de Bariloche. Report of the Project Conservation, Management and Sustainable Use of Forest Genetic Resources with reference to Brazil and Argentina. International Plant Genetic Resources Institute, Rome, Italy.

Heusser CJ, Rabassa J, Brandant A, Stuckenrath R (1988). Late-Holocene vegetation of the Andean Araucaria region, Province Neuquen, Argentina. Mountain Research and Development 8: 53-63. doi: $10.2307 / 3673406$

Hoffmann A, Sierra M, Prosser C, Valle M (2001). Enciclopedia de los bosques chilenos. Gráfica Andes, Santiago, Chile.

IUCN (1996). World list of threatened trees. International Union for the Conservation of Nature, Gland, Switzerland. [online] URL: http://www.iucn.org/about/work/programmes/spe cies/red_list/

Martín MA, Martín LM, Álvarez JB (2005). Cotyledon storage proteins in European sweet chestnut. Acta Horticulturae 693: 459-463.
Martín MA, Martín, LM, Álvarez JB (2008). Uso de las proteínas de reserva del megagametofito como marcador de la diversidad genética en Abies pinsapo. Cuad. Soc. Esp. Cienc. For. 24: 63-66.

Montaldo PR (1974). La bio-ecología de Araucaria araucana (Mol.) Koch. Instituto Forestal Latino-Americano de Investigación y Capacitación Boletín 46-48: 1-55.

Movimiento Mundial por los Bosques (1998) Chile: un modelo forestal insustentable. Boletín no. 13. [online] URL: http://www.wrm.org.uy/ boletin/13/chile.html

Muñoz RI (1984). Análisis de la productividad de semillas de Araucaria araucana (Mol.) C. Koch. En el área de Lonquimay-IX Región. PhD thesis, University of Chile, Santiago, Chile.

Muñoz-Diez C (2008). Prospección, diversidad genética y conservación de ejemplares monumentales y poblaciones silvestres de olivo (Olea europaea L.). PhD thesis, University of Cordoba, Spain.

Mutarelli E, Orfila E (1992). Ensayo de tratamientos experimentales en bosques de Araucaria araucana (Mol.) C. Koch. en la zona del Lago Moquehue, provincia de Neuquén, Argentina. Rev For Arg 14 (4): 109-117.

Paulsch A (1994). Verjüngungsstrategien von Araucaria araucana (Mol.) Koch. in Waldgesellschaften Südchiles. Master dissertation, Universität Bayreuth, Germany.

Peraza (2008). Determinación de las áreas prioritarias de actuación en masas de Araucaria araucana (Mol.) K. Koch de Chile. Trabajo Profesional Fin de Carrera, ETSIAM, University of Cordoba, Spain.

Rafii ZA, Dodd RS (1998). Genetic diversity among coastal and Andean natural populations of Araucaria araucana (Molina), K. Koch. Biochem Syst and Ecol 26: 441-451. - doi: 10.1016/S0305-1978(97)00125-7

Schilling R, Donoso C (1976). Reproducción vegetative natural de Araucaria araucana (Mol.) C. Koch. Investigaciones Agricultura (Chile) 2: 121-122.

Tortorelli L (1942). La explotación racional de los bosques de araucaria de Neuquén. Servir 6: 1-53. Turner M (2001). Landscape ecology in theory and practise. Springer-Verlag, Berlin, Germany. Veblen TT (1982). Regeneration patterns in Araucaria araucana forest in Chile. Journal of Biogeography 9: 11-28. - doi: 10.2307/2844727 Veblen TT, Burns BR, Kitzberger T, Lara A, Villalba R (1995). The ecology of the conifers of southern South America. In: "Ecology of the southern conifers" (Enright N, Hill R eds). Melbourne, pp. 120-155. 